\title{
COMPLEX OF SUGGESTIONS ON IMPROVING THE PSYCHOLOGICAL CORRECTION AND DIAGNOSTICS OF TRAUMATIC EMOTIONAL EXPERIENCE AMONG MILITARY SERVANTS WITH POST-STRESS PSYCHOLOGICAL DYSAPTATION
}

\author{
Andriy O. Kharchenko \\ Department of psychological counseling and psychotherapy, faculty of psychology, V.N. Karazin KhNU, \\ Kharkiv, 61077, Ukraine \\ E-mail: kharchenkoao091284@gmail.com,https://orcid.org/0000-0001-6685-1498
}

\begin{abstract}
Problem statement: Resistance to the impact of psychocorrectional and psychotherapeutic work on the personality of servicemen in Ukraine with post-stress psychological maladaptation and experience of participation in combat operations with traumatic background and multiparametric approaches in this area, become significant reasons for more detailed analysis in psychological diagnostics of harmful knowledge among military members. Analysis of the problem There are many inventions in science on the conceptualization of personal traumatic experience at both clinical (PTSD) and prenosological (PPD) levels. The idea of "emotional scheme" proposed by L. Greenberg and R. Elliott is successful for the latter, but the question of psychodiagnostics and psychocorrection for traumatic emotional experience among demobilized combatants in Ukraine with PPD remains open. Object of study - to develop a set of suggestions for psychocorrection and diagnostics of traumatic emotional experience among servicemen after demobilization in Ukraine with PPD. Research methods - Mathematical and statistical processing: Wilcoxon T-test. Sample description The sample consists of 12 servicemen after demobilization six months or a year later in Ukraine with PPD. They agreed to be tested and participate in psycho-correctional work on the issues of significant traumatic emotional experience. Summary A set of suggestions for psychocorrection and diagnostics of traumatic emotional experience among servicemen in Ukraine with post-stress psychological maladaptation has been developed.
\end{abstract}

KEY WORDS: servicemen, PPD, diagnostics, psychocorrection, traumatic emotional experience.

Problem statement: According to various data, from 20 to 90 percent of people who participated or witnessed stressful situations, further receive a subclinical level of maladaptation (post-stress psychological maladaptation - PPD). During the ATO-JFO in eastern Ukraine, more than 200,000 military men served in the Armed Forces, which gives new impetus to the study for the adaptive potential of these servicemen and the problems of traumatic experience, the occurrence or complication of which significantly impairs the ability to adapt and resocialize. The resistance deteriorates situation of the effectiveness in psycho-correctional and psychotherapeutic work on PTSD and PPD. A new vision in psycho-correctional and psychodiagnostic work with these issues can be provided by the use of "emotional scheme" (proposed in emotional-focused therapy) in the conceptualization of traumatic experience among servicemen.

Analysis of the problem: Peculiarities for manifestation of traumatic experience among servicemen at the nosological level are often associated with such rubrications of the International Classification of Diseases 10 revision as: F43.0; F43.1, which provides a comprehensive description of their respective states. Aspects for manifestation of traumatic experience among servicemen, as different variations of the manifestation in posttraumatic stress disorder, were offered by the results in researches and works of many scientists: L.F. Shestopalova, V.S. Pidkoritova, D.M. Bolotova, I.V. Gurina, Y.A. Alexandrovsky, E.N. Zagoruyko, T.E. Marchuk, A.I. Bilim, B.S. Polozhog, B.D. Tsigankova, J. Bell Meisenhelder, R. Rosner, B.C. Frueh (Voloshyn, 2014).

B.D. Karvasarsky and A.N. Blair note that the subclinical level of personality maladaptation is accompanied by a number of psychological issues, which include: deterioration of autonomy in decision-making, the emotional sphere becomes less regulated, which is manifested by emotional instability and unpredictability; there is a skeptical 
attitude to life and others; aggression, anxiety, irritability, tendency to solitude, deterioration of communicative competencies.

M.V. Markova and P.V. Kozyra point to the existence of multiple mental disorders at the subclinical level, which should be paid much more attention in today's science when addressing mental health issues. They also point to the necessity to organize and integrate these disorders into existing classifications, which will significantly improve the solution of the problem in psychological work with requests for maladaptation. In turn, they also proposed a list of signs that indicate a high probability of individual psychological maladaptation. These include: the impossibility of previous reactions of the individual, which previously carried resilience to adaptive nature; limited affective beliefs or attitudes, on which all the attention and most of the psychological activity is concentrated; rigidity; anxiety; deterioration of volitional processes and the emergence of destabilizing processes in the emotional sphere.

The most successful inefficiency of the psyche's response to stressful situations, according to Markova M.V. and Kozyra P.V., reflects the concept of "post-stress psychological maladaptation", which characterizes the deterioration of adaptation at the cognitive, behavioral and emotional levels (Kozyra, 2017). In the dissertation research, which was headed by O.S. Kocharyan we used theory of "emotional scheme" to conceptualize traumatic experience among servicemen, namely emotional, which was a very good option in the study of this psychological structure (the concept proposed by L. Greenberg and R. Elliott (2004) in procedural-experimental psychotherapy). Motivation, cognitive sphere, system of memories and bodily manifestations are united by emotions into a single structure. If in this structure, as a core component, emotions acquire a traumatic, "congestion" (this idea was proposed by Kocharyan O.S. (2014)) character, then the whole structure generally forms a single system of individual traumatic emotional experience. In studies led by Kocharyan O.S. there is the significant impact of emotional experience on the personal psychological health. The question of effectiveness in psychodiagnostics and psychocorrection for these structures remains open, so developments in this direction can improve psychodiagnostic and psychocorrectional work with the structures of traumatic, namely, emotional experience of servicemen with PPD.

Object of study - to develop a set of suggestions for effective psychocorrection and diagnostics of traumatic experience (emotional) among servicemen with post-stress PD in Ukraine which have experience in military operation.

Sample description. The sample consisted of 12 servicemen who had experience of military participation in Ukraine. They agreed to be tested and take part in psycho-correctional work on issues of significant traumatic emotional experience. The severity of post-stress psychological maladaptation was determined by using the Mississippi scale, namely its military version. The evidence of traumatic emotional experience was determined by high scores on appropriate methods, which are listed in the general register of psychological research methods.

Methods: Mathematical and statistical processing: Wilcoxon T-test.

\section{Results of research. Objectivation.}

When testing servicemen in order to identify the structural features of their traumatic experience, namely, emotional, 12 men agreed to participate in psycho-correctional work on this topic and its more in-depth diagnostics. In Table lists all types of psycho-correctional work that has been done with servicemen on inquiries related to traumatic emotional experiences.

Grawe K. proposed certain general criteria for evaluating the effectiveness of psychocorrection, which formed the basis for determining the results of work carried out with these servicemen. These criteria include: 1) the level of global assessment of achievements; 2) the ability to identify personal psychological issues; 3) improvement in emotional sphere and a higher level of manifestation of abilities; 4) qualitative changes in implementation of communicative competencies; 5) gaining new experience in ability to manage free time; 6) professional success; 7) reduction of complaints in psychophysical manifestations (Itzhaky, 2017). 
Psycho-correctional work with demands in manifestations of traumatic experience among servicemen with PPD

\begin{tabular}{|c|c|}
\hline Parameter & Detailed description \\
\hline $\begin{array}{l}\text { Total number of military } \\
\text { men }\end{array}$ & 12 people \\
\hline \multirow[t]{2}{*}{ Different forms of work } & $\begin{array}{l}\text { Combined: the work was carried out both personally and with inclusion in } \\
\text { the therapeutic group }\end{array}$ \\
\hline & Individual \\
\hline $\begin{array}{l}\text { Psycho-correctional basis } \\
\text { of work }\end{array}$ & CCP approach by K.R. Rogers \\
\hline Methods of work & $\begin{array}{l}\text { Method by A.F. Yermoshin, the technique of reflection and empathy, the } \\
\text { technique of CBT, the approach by D. Berzelli, the method of systematic } \\
\text { dissensitization. }\end{array}$ \\
\hline \multirow{2}{*}{$\begin{array}{l}\text { Time for } \\
\text { psychocorrection }\end{array}$} & hours \\
\hline & 20 \\
\hline Duration of work & Two and a half months \\
\hline Frequency of meetings & Once a week \\
\hline \multirow[t]{2}{*}{ Meeting duration } & hours \\
\hline & two \\
\hline $\begin{array}{l}\text { Psychological complaints } \\
(\%)\end{array}$ & $\begin{array}{l}\text { Inadaptive thoughts and emotional discomfort (100); dissatisfaction in } \\
\text { communication with others (83.3); unwillingness to take personal } \\
\text { opportunities seriously ( } 75) \text {; low level of motivation }(91.7) \text {; deterioration } \\
\text { of physical condition due to psychological problems }(66,6) \text {; problems of } \\
\text { resocialization after service (100); complaints about the general psycho- } \\
\text { emotional state (83.3); complaints of dreaming (58.3); ignorance of how } \\
\text { to deal with memories (75). }\end{array}$ \\
\hline Amount of participants & 12 \\
\hline Efficiency label & Proven \\
\hline
\end{tabular}

Grawe K. proposed certain general criteria for evaluating the effectiveness of psychocorrection, which formed the basis for determining the results of work carried out with these servicemen. These criteria include: 1) the level of global assessment of achievements; 2) the ability to identify personal psychological issues; 3) improvement in emotional sphere and a higher level of manifestation of abilities; 4) qualitative changes in implementation of communicative competencies; 5) gaining new experience in ability to manage free time; 6) professional success; 7) reduction of complaints in psychophysical manifestations (Itzhaky, 2017).

To determine the effectiveness of psychocorrectional work with complaints related to the manifestation of traumatic experience, the independent experts who used the above criteria according to Grawe K. were involved. Each serviceman received from the expert a score from 1 to 10 as an indicator of the criterion in a relevant indicator for his life. The evaluation was conducted at first and last meeting, the results were compared using the Wilcoxon test. For all criteria, the Wilcoxon test score indicated significant differences between the first and second testing scores, provided that they all were improved after appropriate psychocorrectional work.

Thus, the effectiveness of this work has been proven taking into account many parameters of military life that make these results more reliable compared to single-scale assessment options. 
Psychological work with servicemen who mostly have complaints caused by the manifestation of traumatic experience, made it possible to develop a certain optimal system for diagnostics of these structures, taking into account the "emotional scheme" idea, which reveals each of its components. Below one can find a list of psychometric tools that have effectively proven themselves in identifying features of each component in this scheme, as ideas for conceptualizing the traumatic emotional experience among servicemen.

- Diagnostics of maladaptive schemes, the importance of which is indicated by Young J., was implemented using methodology developed by him;

- Diagnostics of components in emotional scheme was as follows:

- Directly the experience itself, which has a traumatic component, was detected with the use of SDE by Izard $\mathrm{K}$. and the questionnaire by Rabinovich L.A. to diagnose basic emotions. Results by the method of J. Young are compared with the relevant methods to identify the characteristics for manifestation of "congestion" experiences,

- Early memories were detected using the appropriate technique proposed by W. R. Rule,

- Manifestations of traumatic experience at the level of physicality were diagnosed using questionnaires SF - 36 and Assessment of neuropsychological stress, the author of which is Nemchin T.A.;

- The structure of cognitive representation was diagnosed using a texturized interview;

- Features of the motivation system were identified using TIM TSO (by Leontiev D.A.);

- $\quad$ Early psychological traumas were identified through the Burbo L. test.

Additional in the diagnostics for traumatic experiences of servicemen were the Mississippi scale, as well as scales: Impact of Event Scale-R IES-R and Symptom Check List-90-Revised - SCL90-R,

For more detailed psychodiagnostic work in finding features of traumatic experience manifestation, the methods and techniques listed in Table 1 were used, for the application of which, including in direct work with servicemen, there are certain developments (Kharchenko, 2019; Myers, 2019; Chen, 2018).

The result in psycho-correctional work with the complaints of servicemen caused by the manifestation of traumatic emotional experience was development of proposals for optimizing the relevant work:

1. When planning and implementing psychocorrectional work on the manifestations of traumatic experience among servicemen, it is important and effective to use a comprehensive approach that provides simultaneous or phased focus on all components of the emotional scheme, which include early memories, traumatic experiences, maladaptive cognitive representations of this experience, motivational-semantic sphere and manifestations at the bodily level.

2. The eventual result of psycho-correctional work includes replacement of the current scheme, that carries a traumatic component, with a new, more adaptive and constructive, which should apply to all its components.

3. An important aspect is the integration of updated components into the overall system, that will lead to the transformation of other components, which, in turn, will become cyclical with the gradual improvement of this scheme, i.e. traumatic experience will lose its traumatic nature and become more adaptive. Otherwise, there will be a possibility of returning to the destructive, previous variation of the structure in this experience and minimizing the sanogenicity of processes.

4. The level of sanogenicity in psychocorrectional work can be significantly improved by using such mechanisms as awareness, reflection and emotional equalization.

5. One of the most important recommendations in working with traumatic experiences is to avoid retraumatization among servicemen. This experience includes a whole conglomeration of infantile traumas that can be potentiated by current, rather complex experiences, so it is important to use techniques carefully, which minimizes the actualization of these traumas and will allow to preserve the adaptive potential of the individual. 
6. Effective techniques in psycho-correctional work with the traumatic experience of the military men: the approach of A.F. Yermoshina, CCP techniques, CBT, Berzelli D. method and systemic dissensitization.

7. At the initial stage, it is important to establish a collaborative format of interaction, which is informative, regulatory and managing in nature, because this level of communication is more tuned by servicemen. Therefore, the immediate transition to techniques that involve working with emotions can cause anxiety and worry and, as a result, reluctance to continue working. Therefore, it is recommended to start with CBT, psychocatalysis or TRE.

8. The development of a more adaptive, functional scheme involves its consolidation, for which preventive work that should last about 3 months is recommended.

\section{Summary}

1. Diagnostics of structural features in traumatic emotional experience among servicemen who participated in combat actions, involves identifying the features of the manifestation for all components in the "emotional scheme", the idea of which is proposed as a conceptualization of traumatic experience. To identify the features of these components, namely: traumatic experiences, the structure of early memories, bodily manifestations, motivational semantic sphere and cognitive representations, there were selected using psychometric tools.

2. During the psychodiagnostic work with servicemen, the following were used to clarify the main range of complaints related to the manifestation of the components of the "emotional scheme": (military version) Mississippi scale for determining the level of post-traumatic reactions, SDE according to Izard K. (Scale of Differential Emotions); in the work with early memories there was used a questionnaire by W.R. Rule, questionnaire by Rabinovich L.A. for diagnostics of basic emotions, test by Burbo L. for diagnostics of five infantile psychological traumas, structured interview for the diagnostics of maladaptive cognitive structures, TIM - a test for diagnostics of individual motivation, test by Leontief D.A. to identify meaningful life orientations, scale for rating the degree of impact from the traumatic event, a questionnaire for the diagnostics of psychopathological symptoms.

3. When carrying out psycho-correctional work, the methods by D. Berzelli and A.F. Yermoshina, CCP and CBT technicians have proved to be effective. A set of proposals for optimizing psycho-correctional work with complaints of servicemen due to the manifestation in traumatic emotional experience has been developed.

\section{REFERENCES}

Chen, Jessica A.; Fortney, John C.; Bergman, Hannah E.; Browne, Kendall C.; Grubbs, Kathleen M.; Hudson, Teresa J.; \& Raue, Patrick J. Darryl. (2018). Therapeutic alliance across trauma-focused and non-trauma-focused psychotherapies among veterans with PTSD. Traumatology, 25(4), 221-234.

Elliot R., Watson J. C., Goldman R.N., Greenberg L.S. (2004). Lerning emotion-focused therapy: the processexperiential approach to change. American Psychological Association.

Itzhaky, Liat, Stein, Jacob Y., Levin, Yafit, Solomon, Zahava. (2017). Posttraumatic stress symptoms and marital adjustment among Israeli combat veterans: The role of loneliness and attachment. Psychological Trauma: Theory, Research, Practice, and Policy, $9(6), 655-662$.

Kharchenko A.O. (2019). Психологічні особливості структури травматичного емоційного досвіду демобілізованих учасників бойових дій в Україні 3 постстресовою психологічною дезадаптацією [Psychological features of the structure of traumatic emotional experience of demobilized combatants in Ukraine with post-stress psychological maladaptation]. Kharkiv: V.N. Karazin Kharkiv national university.

Kocharyan A.S. (2014). Переживание как мишень клиентцентрированной психотерапії [Experience as a target of client-centered psychotherapy]. Psychological counseling and psychotherapy, 1-2, 24-36.

Kozyra P.V. (2017). Дезадаптивні стани та йіх корекція у співробітників МВС - учасківкі бойових дій. Дисертація на здобуття учбового ступеня кандидата психологічних наук для спечіальності 19.00.04. медична психологія [Disadaptive states and their correction in employees of the Ministry of Internal Affairs - participants in hostilities. The dissertation on competition of a scientific degree of the candidate of psychological sciences, for a specialty 19.00.04. - medical psychology]. Kharkiv: Kharkivs'ka medychna akademiya pislyadyplomnoyi osvity MOZ Ukrayiny.

Myers, Ursula S., Haller, Moira, Angkaw, Abigail C., Harik, Juliette M., Norman, Sonya B. (2019). Evidence-based psychotherapy completion and symptom improvement 
among returning combat veterans with PTSD. Psychological Trauma: Theory, Research, Practice, and Policy, 11(2), 216-223.

Voloshyn P.V., Maruta N.O., Shestopalova N.F., Lins'kyy I.V., Pidkorytov V.S., Lipatov I.I., Buchok Yu.S.,
Zavorotnyy V.I. Diahnostyka, (2014). Terapiya ta profilaktyka medyko-psykholohichnykh naslidkiv boyovykh diy $v$ suchasnykh umovakh: metodychni rekomendatsiyi. Kharkiv: DU «Instytut nevrolohiyi psykhiatriyi ta narkolohiyi NAMN Ukrayiny».

\section{КОМПЛЕКС ПРОПОЗИЦЙ ЩОДО ВДОСКОНАЛЕННЯ ПСИХОЛОГІЧНОЇ КОРЕКЦІЇ ТА ДІАГНОСТИКИ ТРАВМАТИЧНОГО ЕМОЦІЙНОГО ДОСВІДУ СЕРЕД ВІЙСЬКОВОСЛУЖБОВЦІВ 3 ПІСЛЯСТРЕСОВОЮ ПСИХОЛОГІЧНОЮ ДЕЗАДАПТАЦІЮ \\ Харченко А.О.}

Кафедра психологічного консультування та психотерапї̈, факультет психології, В.Н. Каразіна ХНУ,

Харків, 61077, Україна

Постановка проблеми. Резистентність щодо впливу психокорекційної та психотерапевтичної роботи на особистість військовослужбовців в Україні з постстресовою психологічною дезадаптацією, які мають досвід участі в бойових діях в роботі з травматичним досвідом та поліпараметричність підходів у цій сфері, стають суттєвими причинами у виникненні необхідності більш детального розгляду питання психологічної діагностики та психокорекції травматичного досвіду військовослужбовців. Аналіз проблеми. В науці існує багато напрацювань щодо концептуалізації травматичного досвіду особистості як на клінічному (ПТСР) так і на донозологічному (ППД) рівнях. Вдалою для останнього є ідея «емоційної схеми», запропонованої Л.Грінбергом та Р.Элліоттом, проте залишається відкритим питання психодіагностики та психокорекції травматичного емоційного досвіду у демобілізованих учасників бойових дій в Україні з ППД. Мета дослідження - розробити комплекс пропозицій з психокорекції й діагностики травматичного емоційного досвіду у військовослужбовців після демобілізації в Україні з ППД. Методи дослідження. Математико-статистична обробка: Т - критерій Вілкоксона. Опис вибірки. Вибірку склали 12 військовослужбовців після демобілізації через півроку чи рік в Україні з ППД, які погодилися пройти тестування та прийняти участь у психокорекційній роботі 3 питань вираженого травматичного емоційного досвіду. Висновки. Розроблено комплекс пропозицій щодо психокорекції та діагностики травматичного емоційного досвіду військовослужбовців в Україні з постстресовою психологічною дезадаптацією.

КЛЮЧОВІ СЛОВА: військовослужбовці, ППД, діагностика, психокорекція, травматичний емоційний досвід.

\section{КОМПЛЕКС ПРЕДЛОЖЕНИЙ ПО СОВЕРШЕНСТВОВАНИЮ ПСИХОЛОГИЧЕСКОЙ КОРРЕКЦИИ И ДИАГНОСТИКИ ТРАВМАТИЧЕСКОГО ЭМОЦИОНАЛЬНОГО ОПЫТА СРЕДИ ВОЕННОСЛУЖАЩИХ С ПОСЛЕСТРЕССОВОЙ ПСИХОЛОГИЧЕСКОЙ ДЕЗАДАПТАЦИЕЙ}

Харченко А.А.

Кафедра психологического консультирования и психотерапии, факультет психологии, В.Н. Каразина ХНУ,

Харьков, 61077, Украина

Постановка проблемы. Резистентность касательно влияния психокоррекционной и психотерапевтической работы на личность военнослужащих в Украине с постстрессовой психологической дезадаптацией, которые имеют опыт участия в боевых действиях в работе с травматическим опытом и полипараметричность подходов в этой сфере, становятся существенной пчичиной в возникновении необходимости более детального рассмотрения вопроса психологической диагностики и психокоррекции травматического опыта военнослужащих. Анализ проблемы. В науке существует много наработок концептуализации травматического опыта личности как на клиническом (ПТСР) так и на донозологическом (ППД) уровнях. Удачной для последнего есть идея «емоциональной схемы», предложеной Л. Гринбергом та Р. Эллиоттом, однако остаётся открытым вопрос психодиагностики и психокоррекции травматического емоционального опыта у демобилизированных учасников боевых действий в Украине с ППД. Цель исследования - разработать комплекс предложений для психокорекции и диагностики травматического эмоционального опыта у военнослужащих после демобилизации в Украине с ППД. Методы исследования. Математико-статистическая обробка: Т - критерий Вилкоксона. Описание выборки. Выборку составили 12 военнослужащих после демобилизации (от полугода до года) в Украине с ППД, которые согласились пройти тестирование и принять участие в психокоррекционной работе по вопросам выраженного травматического эмоционального опыта. Bblвoды разработано предложения касательно психокоррекции и диагностики травматического эмоционального опыта военнослужащих в Украине с постстрессовой психологической дезадаптацией.

КЛЮЧЕВЫЕ СЛОВА: военнослужащие, ППД, диагностика, психокоррекция, травматический емоциональный опыт. 